\title{
Determining lateral resistance of sleeper in railway ballast
}

\author{
Zdeněk Hřebíček ${ }^{1}$, Vladimír L'upták ${ }^{1}$, * Mária Stopková ${ }^{1}$ \\ ${ }^{1}$ Institute of Technology and Business in České Budějovice, Okružní 517/10, 37001 České Budějovice, Czech Republic
}

\begin{abstract}
Within a project of Technology Agency of the Czech Republic No. TA 04030889 "Operational diagnostic of qualitative indicators of railway tracks by means of gauging its spatial deformation." Empirical cross-resistance tests of sleepers in railway ballast were carried out in geotechnical laboratory test field (GLTF) of the Transport research center in Brno (TRC). The tests were done in collaboration with Czech Technical University in Prague, Department of Railway Structures (ČVUT).
\end{abstract}

\section{Description of the testing equipment}

Geotechnical laboratory test field in the picture 1 is a unique technical device registered by Office for Patents and Inventions as a Utility Model on which tests for laboratory structural body layers of rail bottoms and for rail superstructures regarding the current simulation effects of a different operating load and climatic conditions can be done. The laboratory equipment allows performing destructive and non-destructive tests of building materials and constructions. The workplace is also equipped with modern information technology supplied with appropriate software. The structural organization of GLTF is depicted in Figure 2. [1]

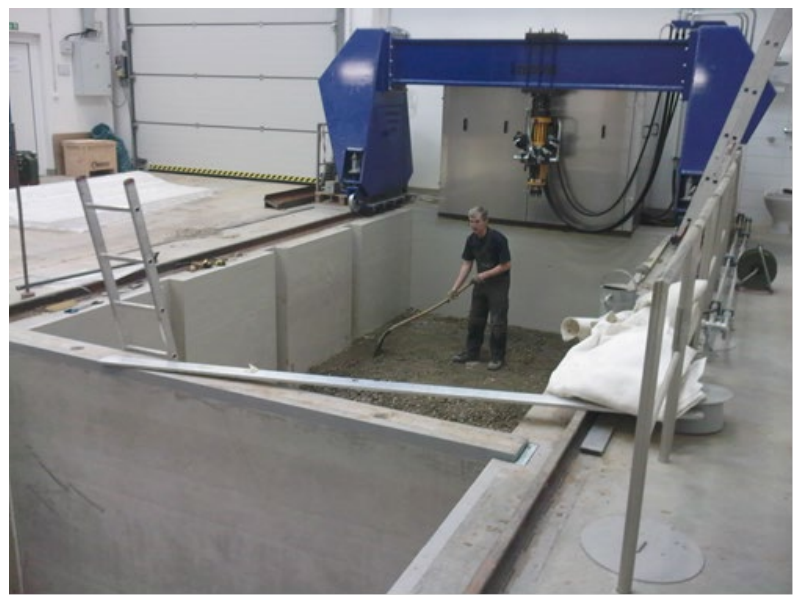

Fig. 1 Geotechnical laboratory testing field

For laboratory testing purposes within the problematics, a railway track model in the scale 1:1 was implemented. Modeling procedure: Establishment of the ground plane, determination of the bearing capacity of the railway underbody body by static loading test, construction of the track bed plan below the sleeping area of the sleeping area and laying of the rail grid. [2, 3]

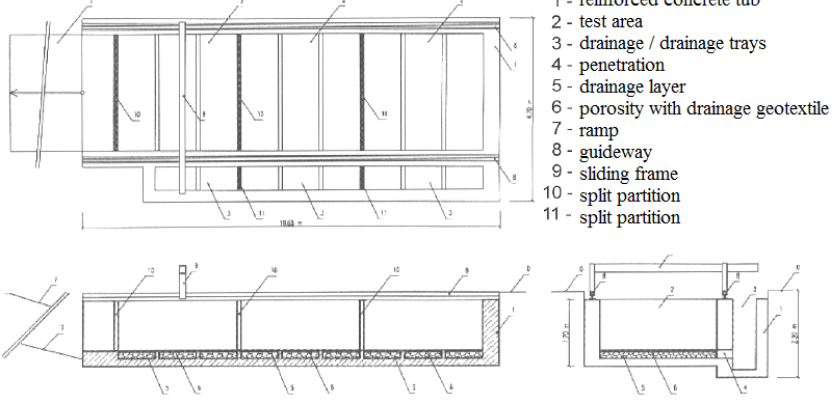

Fig. 2 Structural scheme of geotechnical laboratory test field

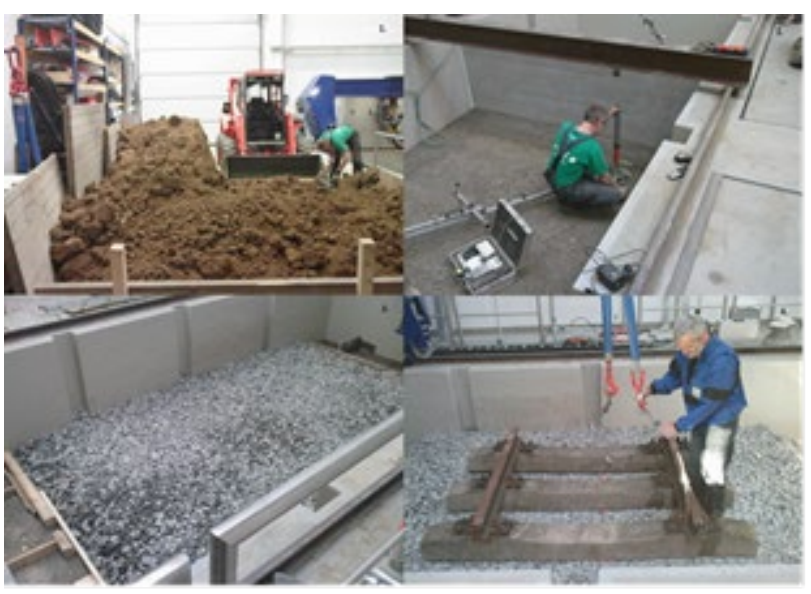

Fig. 3 Geotechnical laboratory testing field

\section{Calculating the thickness of structural body layers of the rail bottom of the track model on GLTF - input data}

Track bed ballast is made of sandy clay, layer thickness $300 \mathrm{~mm}$, capacity of the track bed ballast is calculated to

\footnotetext{
*Corresponding author: luptak@mail.vstecb.cz
} 
$\mathrm{E} 0=20 \mathrm{MPa}$. Track bed of the body of the rail bottom, required load capacity $\mathrm{Epl}=40 \mathrm{MPa}$ (for main tracks of the current national and other railways; see Tab. 1 and 4, attachment 6, regulation S4). The estimated thickness of the structural layer is $400 \mathrm{~mm}$. Ballast compositions type 2, construction material: gravel, fraction $0 / 32$, material consistency of the track bed ballast - solid (sandy clay). Suggested thickness of the structural layer $400 \mathrm{~mm}$. Reduction factor $\mathrm{z}=0.8$. Reduced module of deformation of track bed ballast $\mathrm{E} 0 \mathrm{r}=0.8 . \quad 20=16$ $[\mathrm{MPa}]$. Module of deformation of the structural layer $\mathrm{E} 1=60 \mathrm{MPa}$. [4]

Calculation:

Where they mark:

$$
\begin{gathered}
k_{1}=E_{0 r} / E_{1}=16 / 60=0.27 \\
k_{2}=h_{1} / D=0.40 / 0.30=1.33
\end{gathered}
$$

$\mathrm{E}_{0 \mathrm{r}}$ - reduced module of deformation of track bed ballast [MPa],

$\mathrm{E}_{1}$ - module of deformation of the structural layer [MPa], $\mathrm{h}_{1}$ - thickness of the structural layer [m],

$\mathrm{D}$ - diameter of the load plate [m].

$\mathrm{K}_{3}$ - is determined from the diagram in Pict. 8, attachment 6 , regulation $\mathrm{S} 4$

$\mathrm{K}_{3}-0.71$

The equivalent module of deformation of a two-layer construction of the rail bottom body

$$
E e 1=k 3 . E 1=0.71 .60=42.60>40[\mathrm{MPa}]
$$

Qualitative parameters of the material of the ballast body and structural layers.

Track bed - Ballast from the vicinity of Křivá Borovice, Olomoučany

Locality:

Geomorphological classification:

- System - Hercynský

- Subsystem - Hercynská pohoří

- Province - Česká Vysočina

- Subprovince- Česko-moravská

- Region - Brněnská vrchovina

Geological region: Moravia-Silesia region - borderline of Moravian-Silesia Paleozoic (Moravský Kras) and brunovistulic (Brněnský masív). [5,6]]

Table 1. Further classification

\begin{tabular}{|l|l|}
\hline \multicolumn{2}{|c|}{ Further classification } \\
\hline Sandy clay & $\mathrm{F} 4 \mathrm{CS}$ \\
\hline gravel fraction ratio & $\mathrm{g}=8.1 \%$ \\
\hline sand fraction ratio & $\mathrm{s}=46.6 \%$ \\
\hline ratio s/g & $\mathrm{f}=45,3 \%$ \\
\hline Natural soil humidity & $\mathrm{w}=20 \%$ \\
\hline $\mathrm{CBR}$ (when $\mathrm{w}=14.7 \%)$ & $\mathrm{CBR}=17 \%$ \\
\hline $\mathrm{CBR}$ (when $\mathrm{w}=20.2 \%)$ & $\mathrm{CBR}=5 \%$ \\
\hline $\mathrm{W}_{\text {opt }}$ & $18.0 \%$ \\
\hline $\begin{array}{l}\text { Max. density Proctor Standard } \\
\text { pd,max PS }\end{array}$ & $1720 \mathrm{~kg} / \mathrm{m}^{3}$ \\
\hline Liquid limit & $\mathrm{WL}=37.2$ \\
\hline Plasticity limit & $\mathrm{WP}=15.2$ \\
\hline Plasticity number & $\mathrm{IP}=22.0$ \\
\hline
\end{tabular}

Structural layer

Locality: Dolní Kounice Quarry - gravel ŠD 0-32 mm
Table 2. Structural layer

\begin{tabular}{|l|l|}
\hline \multicolumn{2}{|c|}{ Structural layer } \\
\hline Coarse-grained gravel & $\mathrm{CGr}(\mathrm{G} 3 \mathrm{G}-\mathrm{F})$ \\
\hline gravel fraction ratio & $\mathrm{g}=70 \%-67 \%$ \\
\hline sand fraction ratio & $\mathrm{s}=27 \%$ \\
\hline ratio s/g & $\mathrm{f}=3 \%-6 \%$ \\
\hline heterogeneity number & $\mathrm{Cu}=27$ \\
\hline curvature number & $\mathrm{Cc}=1.65$ \\
\hline Relative compaction $(\min )$ & $\rho_{d, \min }=1669 \mathrm{~kg} / \mathrm{m}^{3}$ \\
\hline Relative compaction $(\max )$ & $\rho_{d, \max }=2208 \mathrm{~kg} / \mathrm{m}^{3}$ \\
\hline
\end{tabular}

Under the classified sub-grade (F4 - CS) $350 \mathrm{~mm}$ of thickness, there is a $600-\mathrm{mm}$ layer of loess soil (LS) of similar properties. [7]

\section{Ballast cushion}

The new, natural, crushed aggregate of density min. 2 000 kg.m-3, fraction 31.5/63, class BI. Requirements for the aggregate classification are laid down by GTR (General Technical Requirements). The thickness of the ballast cushion from the sleeper is $350 \mathrm{~mm}$. [8]

\section{Load capacity of the ballast cushion}

The data for the model construction of the railway were acquired from values of the empirical research at Department of Railway Structures ČVUT in Prague under the following conditions:

- National railway line in operation

- the ballast cushion of the age $2.5-3.5$ years from the ballast laying; alternatively an older ballast cushion visually regarded as partially polluted (unless defined otherwise)

- The data do not include tests carried out on a heavily polluted ballast cushion and entirely new ballast cushion.

Load capacity on the level of the surface of the ballast cushion (sleeper bed area) - impact test:

Minimum value: $27.8 \mathrm{MPa}$

Maximum value: $72.0 \mathrm{MPa}$

Average value: $51.3 \mathrm{MPa}$

Standard deviation: 9.7 MPa

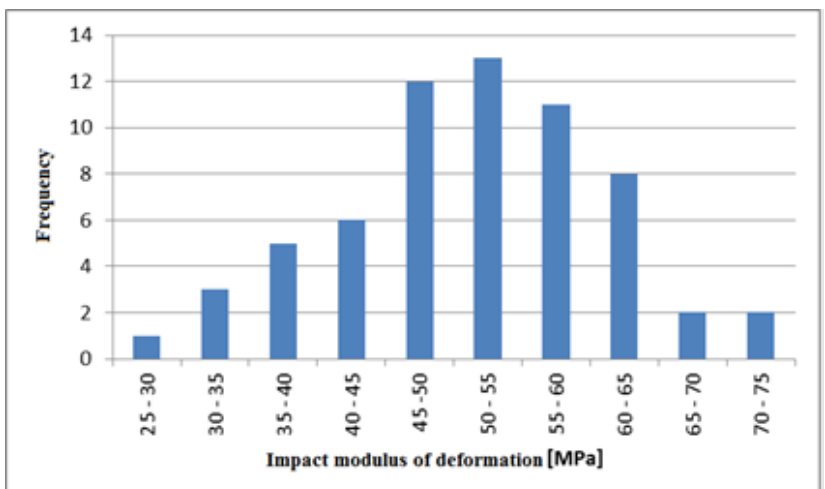

Fig. 4 Frequency chart 
Load capacity on the level of the sleeper bed area impact test:

Minimum value: $40.4 \mathrm{MPa}$

Maximum value: $75.8 \mathrm{MPa}$

Average value: $59.0 \mathrm{MPa}$

Standard deviation: 10.1 MPa. [9]

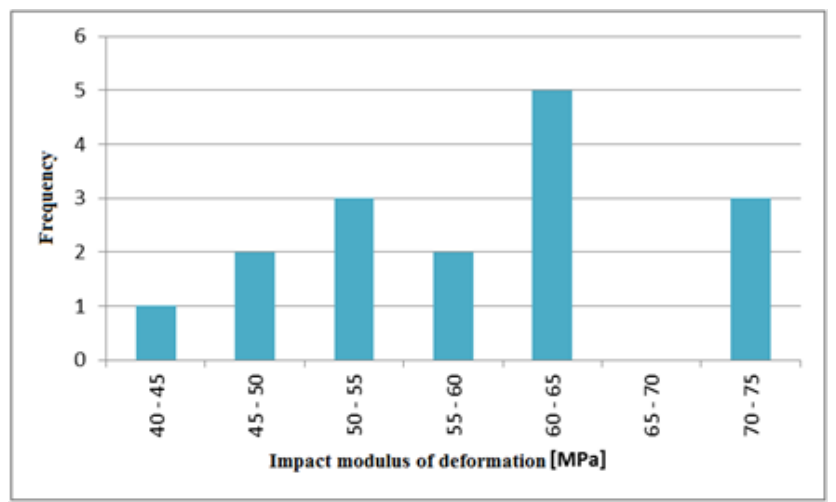

Fig. 5 Frequency chart

The average value of the static module of deformation was, in this case, $71.8 \mathrm{MPa}$ including tests carried out on rails just after a reconstruction. [3]

\section{Rail grid}

Concrete sleepers SB 8 P (see Pict. 6); consolidation of type $\mathrm{K}$ rails; rails $\mathrm{S} 49$, used.

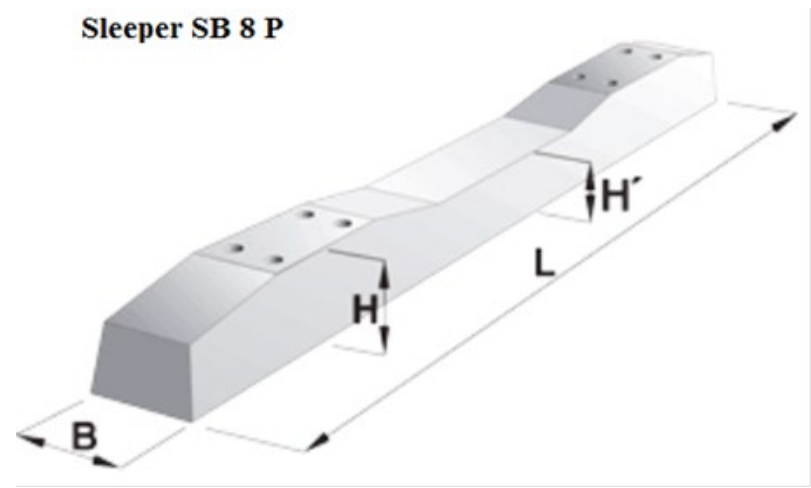

Fig. 6 Concrete sleeper SB 8 P

Table 3. Properties of sleeper

\begin{tabular}{|c|c|c|c|}
\hline trademark & $\begin{array}{c}\text { concrete } \\
\text { class }\end{array}$ & $\begin{array}{c}\text { cubic capacity } \\
\left(\mathrm{m}^{3}\right)\end{array}$ & weight \\
\hline $\begin{array}{c}\text { APP 34- } \\
21\end{array}$ & C 45/55-XF1 & 0,1040 & 270 \\
\hline \multicolumn{4}{|c|}{ Size (cm) } \\
\hline L & B & H & $\mathrm{H}^{\prime}$ \\
\hline 242 & 28,4 & 21 & 15,5 \\
\hline
\end{tabular}

\section{Simulation of the operating load}

Simulation equipment used is pulsator, axle weight 22.5 $\mathrm{t}=225 \mathrm{kN}$ affects the middle of the sleeper through cross-section I profile and spreads through two longitudinal rail profiles to two adjacent sleepers.
Essential requirements:

- Simulated operating load $120000 \mathrm{t}$,

- Train speed $80 \mathrm{~km} \mathrm{~h}-1$,

- Simulated drive of a two-axle freight wagon lbbhps 25 ,

- Axle distance $8000 \mathrm{~mm}$.

Simulated frequency:

$$
f=8 \times 3600 / 80000=0.36 \mathrm{~Hz}=0.36 \mathrm{~s}-1 .
$$

In case of a pulsator being able to exert a force of $22.5 \mathrm{t}$, the simulation lasts $120000 \mathrm{t}$ :

$$
t=0.36 \times 120000 / 22.5=1920 \mathrm{~s}=32 \mathrm{~min} .
$$

\section{Gauging of the rail field}

Within the paper, for the purpose of gauging, a rail field with three sleepers SB $8 \mathrm{P}$, consolidation $\mathrm{K}$, rails S49, axial distance of the sleepers $600 \mathrm{~mm}$, ballast cushion of granularity $31.5 / 63$ and thickness $35 \mathrm{~cm}$ under the sleeper bed area was installed. Sleepers were marked by numbers from 1 to 3 (see Pict. 7). When constructing a model structure, a static impact test was carried out with the following result: deformation module on the level of the track bed of the rail bottom 90 $\mathrm{MPa}$; on the level of the sleeper bed area $93 \mathrm{MPa}$ and on the level of the ballast cushion $82 \mathrm{MPa}$. [10]

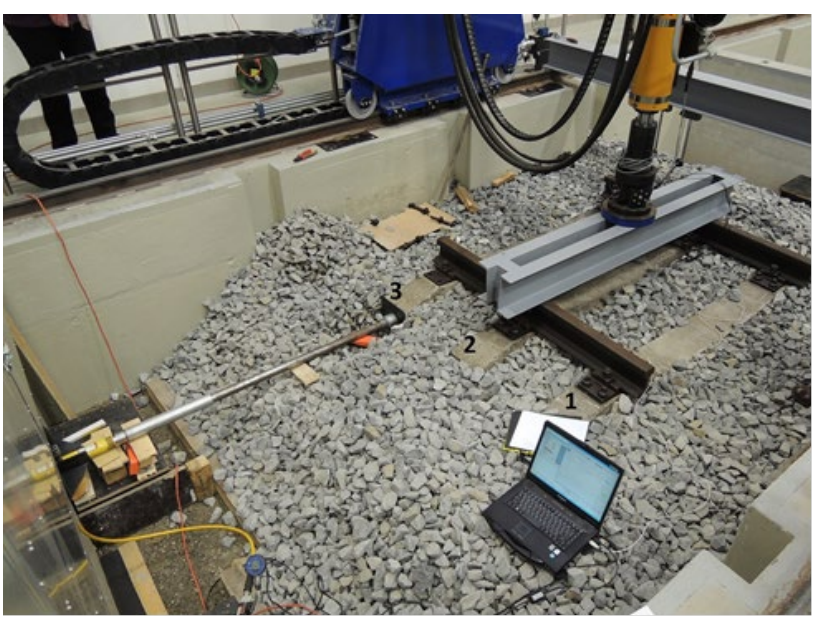

Fig. 7 The test field

Sleeper lateral resistance in the ballast cushion is defined by the value of the force acting in the longitudinal sleeper axis when shifted by $2 \mathrm{~mm}$. During the experiment, gauging of the lateral resistance before and after the cycling of the railway construction model; it lasted 2 hours, frequency $1.5 \mathrm{~Hz}$, amplitude $5-140 \mathrm{Kn}$ (12 000 cycles). The lateral resistance of sleeper No. 1 was gauged before the cycling while that of sleeper No. 2 was gauged after the cycling without an extra load. When gauging the lateral resistance, the chairs of the examined sleeper were always loosened. The railway construction model was subsequently loaded by a force of $\mathrm{Q}=150 \mathrm{kN}$ above the sleeper No. 2 (see Pict. 7) while the lateral resistance of sleeper No. 3 was being gauged. [4-5] 
Furthermore, the shift of sleeper No. 1 of loading was $\mathrm{Q}=0 \mathrm{kN}$ and that of sleeper No. 3 of loading $\mathrm{Q}=40.75$ was $150 \mathrm{kN}$; the load was above sleeper No. 3 and the consolidation on other sleepers was removed. Location of sensors for monitoring sleeper shifts is depicted in Pict. 8. At the same time, a significant decrease of the model in the very place of loading was gauged. The results of the loading are suggested in Pict. 9.

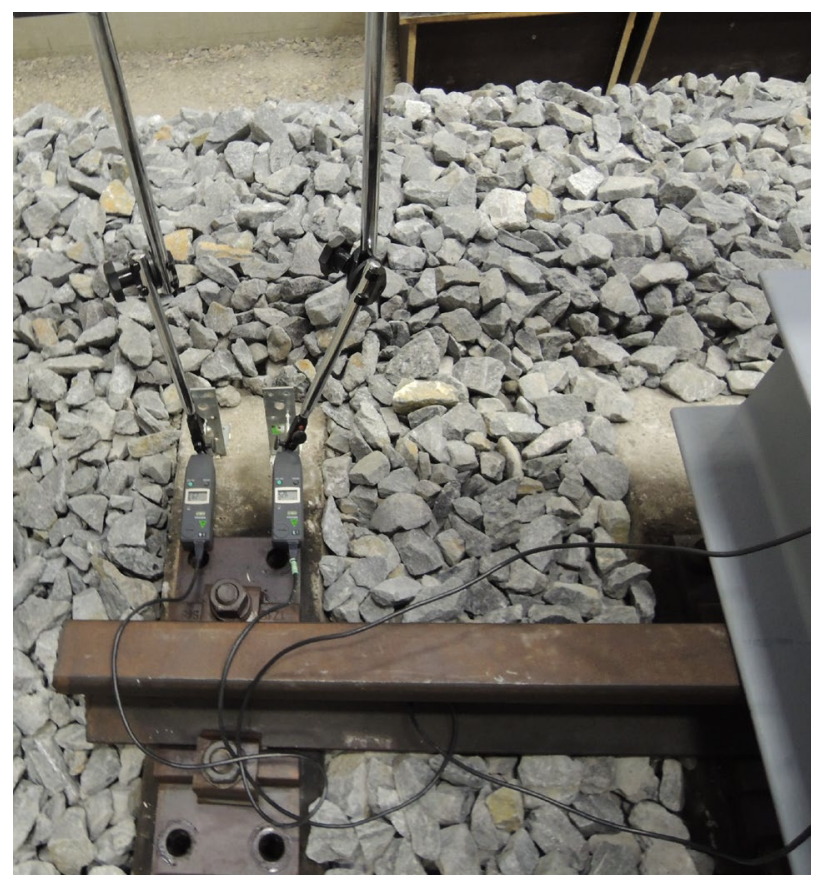

Fig. 8 Location of sensors, when monitoring sleeper shifts

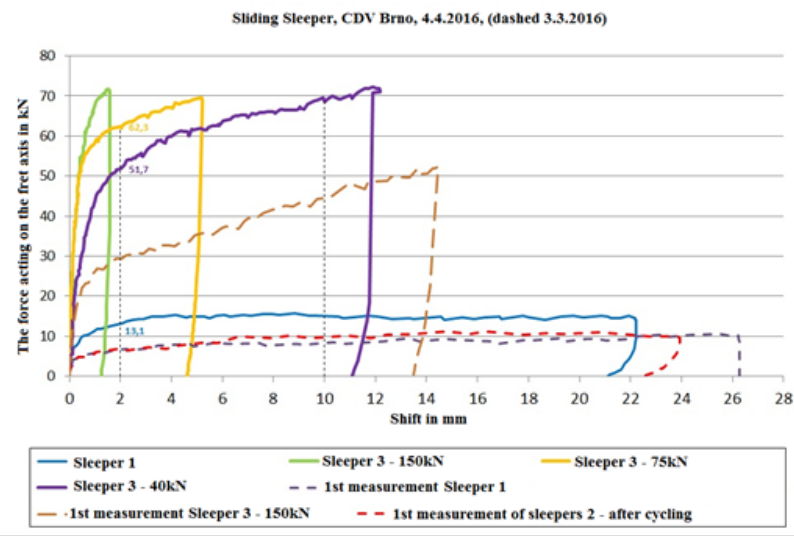

Fig. 9 Graphic view of the results

The research study of gauging the sleeper lateral resistance using variant system of loading shows that its value significantly increases when loading the sleeper; the cyclic loading had only a minimal effect. The experimental results serve as a foundation to calibration of QVW (Querverschiebewiderstand) relationship - the output of the stabilizer DGS90 for assessing the sleeper lateral resistance in the ballast cushion. [6]

\section{Conclusion}

The experimental results were applied in other phases of the project, whose outcome was a certified methodological approach for introducing a new method of quality assessment of carriageways by means of exploring spatial deformations of railway line tracks in regard to specific requirements for track speeds. [8]

The essential requirement is the effective use of track mechanization for dynamic stabilization of ballast cushion DGS - dynamic stabilizer. When switching off the stabilization, so called reference height, which demonstrates continual solidity of the rail, is possible to be registered. The calculation of its standard deviation defines qualitative limits of the rail structure. The next goal is to use the registration equipment for determining the lateral resistance of the rail during its stabilization, to connect the results with the value of the sleeper lateral resistance and thus continually assess the structure condition and its safety as required for continuous welded rails. Using dynamic stabilizer for the rail diagnosis, its weak points in the structure are indicated so that a more ingenious economic plan for repair works of railways can be devised. [9]

\section{References}

1. UIC Project "USP in track", WP 2: Lateral Track Stability, Results from the SBB test track Kiesen/CH, (Measurements done on 03.- 05. 10. 2010).

2. Roel van den Bosch: Querverschiebewiderstandsmessung mit dem dynamischen Gleisstabilisator, EI Eisenbahningenieur (58) 6/2007.

3. Zpráva TA 04030889: Provozní diagnostika kvalitativních ukazatelů koleje železničních tratí měřením její prostorové deformace, 2016.

4. Fendrich Lothar: Handbuch Eisenbahninfrastruktur, ISBN-13 978-3-540-29581-5.

5. A. Plakhin, R. Kampf, E. Ogorodnikova, A. Kokovikhin. 18th International Scientific Conference-Logi $2017 \quad$ (2017). DOI: $10.1051 /$ matecconf $/ 201713400047$

6. B. Abramović, J. Gašparík, V. Zitrický. Tehnički Vjesnik. 25, 4. 1190-1195. (2018),

7. R. Kampf, L. Lizbetinova, K. Tislerova, Open Engineering, 7, 1 (2017)

8. A. Torok. Transport 24, 26-29, (2009) DOI: 10.3846/1648-4142.2009.24.26-29

9. J. Gašparík; B. Abramović, M. Halás. Promet Traffic \& Transportation. 27, 4. 283-290. (2015)

10. V. Zitrický, L. Černá, B.Abramović. Procedia Engineering. 192. 994-999. (2017)

11. J. Gašparík, V. Zitrický. Transport. 25,4. 387-393. (2010) 